\title{
Risk factors and outcomes for the development of malignancy in lung and heart-lung transplant recipients
}

\author{
Michael J Metcalfe BSc${ }^{1}$, Demetrios J Kutsogiannis MD MHS², Kathy Jackson RN BScN², Antigone Oreopoulous MSc², \\ John Mullen MD FRCPS1, Denis Modry MD FRCPS ${ }^{1}$, Justin Weinkauf MD FRCP2, \\ Dale C Lien MD FRCP2 ${ }^{2}$ Ken C Stewart MD FRCPS ${ }^{1}$
}

MJ Metcalfe, DJ Kutsogiannis, K Jackson, et al. Risk factors and outcomes for the development of malignancy in lung and heart-lung transplant recipients. Can Respir J 2010;17(1):e7-e13.

BACKGROUND: Many factors may limit survival from lung and heartlung transplantation, including malignancy.

OBJECTIVE: To investigate factors associated with the development of malignancy following transplantation and its effect on survival by retrospectively reviewing a population of lung transplant recipients.

METHODS: Data from 342 consecutive lung transplant patients were collected. Results were analyzed by fitting variables into a multivariate logistic regression model predicting the development of post-transplant malignancies. Covariates were selected based on crude associations that reached a level of significance at $\mathrm{P} \leq 0.10$. Length of survival was analyzed using the Kaplan-Meier method.

RESULTS: Fifty-eight subjects developed post-transplant malignancies, which were the cause of death of 14 patients. Twenty-one patients had a pretransplant malignancy, of whom six developed a malignancy posttransplant - of these, two were fatal recurrences. No risk factors were significantly associated with all forms of post-transplant malignancy. When adjusted for age at transplantation and donor smoking history, Epstein-Barr virus seropositivity at the time of transplant was significantly associated with a reduced risk of a post-transplant lymphoproliferative disorder (OR $0.17 ; 95 \% \mathrm{CI} 0.05$ to 0.59 ). The median survival time in individuals without a post-transplant malignancy was significantly shorter than in those with a post-transplant malignancy $(\mathrm{P}=0.018 \mathrm{Wilcoxon}$ [Breslow]). This may be secondary to the length of time required to develop malignancy and the fact that not all malignancies that developed were fatal. The median time to develop malignancy was greater than two years. In addition, the 14 patients who died as a result of their malignancy had a significantly shorter survival time than the 44 who died because of nonmalignant causes $(\mathrm{P}<0.001)$.

CONCLUSIONS: Malignancy was not associated with an overall decrease in survival time when compared with those who did not develop a malignancy. Risk factors specific for the development of malignancies remain difficult to specify.

Key Words: Heart and lung transplantation; Lung transplantation; Malignancy; Outcome; Risk factor; Thoracic transplantation

$\mathrm{L}$ ung and heart-lung transplantation have gained widespread acceptance as therapeutic options for patients with limited life expectancy due to advanced lung, or combined heart and lung disease. Transplantation can improve the quality of life and long-term patient survival can be attained (1-3). However, long-term survival remains limited and postoperative complications are frequent. Malignancy has been shown to be a frequent complication of solid organ transplantation and may be an important limitation to long-term survival. The most extensive data regarding post-transplantation malignancy is derived from the renal transplant literature, which indicates an increase

\section{Les facteurs de risque et les issues de l'apparition d'une malignité chez des greffés du poumon et des greffés cœur-poumons}

\begin{abstract}
HISTORIQUE : De nombreux facteurs peuvent limiter la survie après une greffe du poumon ou cœur-poumons, y compris la malignité.

OBJECTIF : Explorer les facteurs associés à l'apparition d'une malignité après une greffe et leurs effets sur la survie grâce à l'analyse rétrospective d'une population de greffés du poumon.

MÉTHODOLOGIE : Les auteurs ont compilé les données de 342 greffés du poumon consécutifs. Ils ont analysé les résultats en insérant les variables dans un modèle de régression logistique multivariée afin de prédire l'apparition de malignités après la greffe. Ils ont sélectionné les covariables selon des associations brutes qui atteignaient un taux de signification à $\mathrm{P} \leq 0,10$. Ils ont analysé la durée de survie au moyen de la méthode de Kaplan-Meier.
\end{abstract}

RÉSULTATS : Cinquante-huit sujets ont présenté une malignité après la greffe, laquelle a provoqué la mort de 14 d'entre eux. Vingt et un patients avaient une malignité avant la greffe; six d'entre eux en ont développé une après la greffe, dont deux se sont révélées fatales. Aucun facteur de risque ne s'associait de manière significative à toutes les formes de malignité après la greffe. Lorsque qu'on procédait aux rajustements compte tenu de l'âge au moment de la greffe et des antécédents de tabagisme, la séropositivité au virus d'Epstein-Barr au moment de la greffe s'associait de manière significative à une diminution du risque de trouble lymphoprolifératif après la greffe (RR 0,17; 95 \% IC 0,05 à 0,59). La durée de survie médiane chez les individus sans malignité après la greffe était considérablement plus courte que chez ceux en présentant une ( $\mathrm{P}=0,018 \mathrm{Wilcoxon}$ [Breslow]). Ce peut être imputable à la période nécessaire pour développer une malignité et au fait que les malignités n'étaient pas toutes fatales. La durée médiane pour développer une malignité était de plus de deux ans. En outre, les 14 patients décédés en raison de leur malignité présentaient une durée de survie beaucoup plus courte que les 44 décédés de causes non malignes $(\mathrm{P}<0,001)$.

CONCLUSIONS : La malignité ne s'associait pas à une diminution globale de la durée de survie par rapport à l'absence de malignité. Les facteurs de risque propres à l'apparition de malignités demeurent difficiles à préciser.

\footnotetext{
${ }^{1}$ Department of Surgery; ${ }^{2}$ Department of Medicine, University of Alberta, Edmonton, Alberta

Correspondence: Dr Dale C Lien, University of Alberta, Walter C Mackenzie Health Sciences Centre 2 45, 8440-112th Street Northwest,

Edmonton, Alberta T6G 2B7. Telephone 780-407-7359, fax 780-407-6384, e-mail dale.lien@ualberta.ca
} 
TABLE 1

Patient demographic data

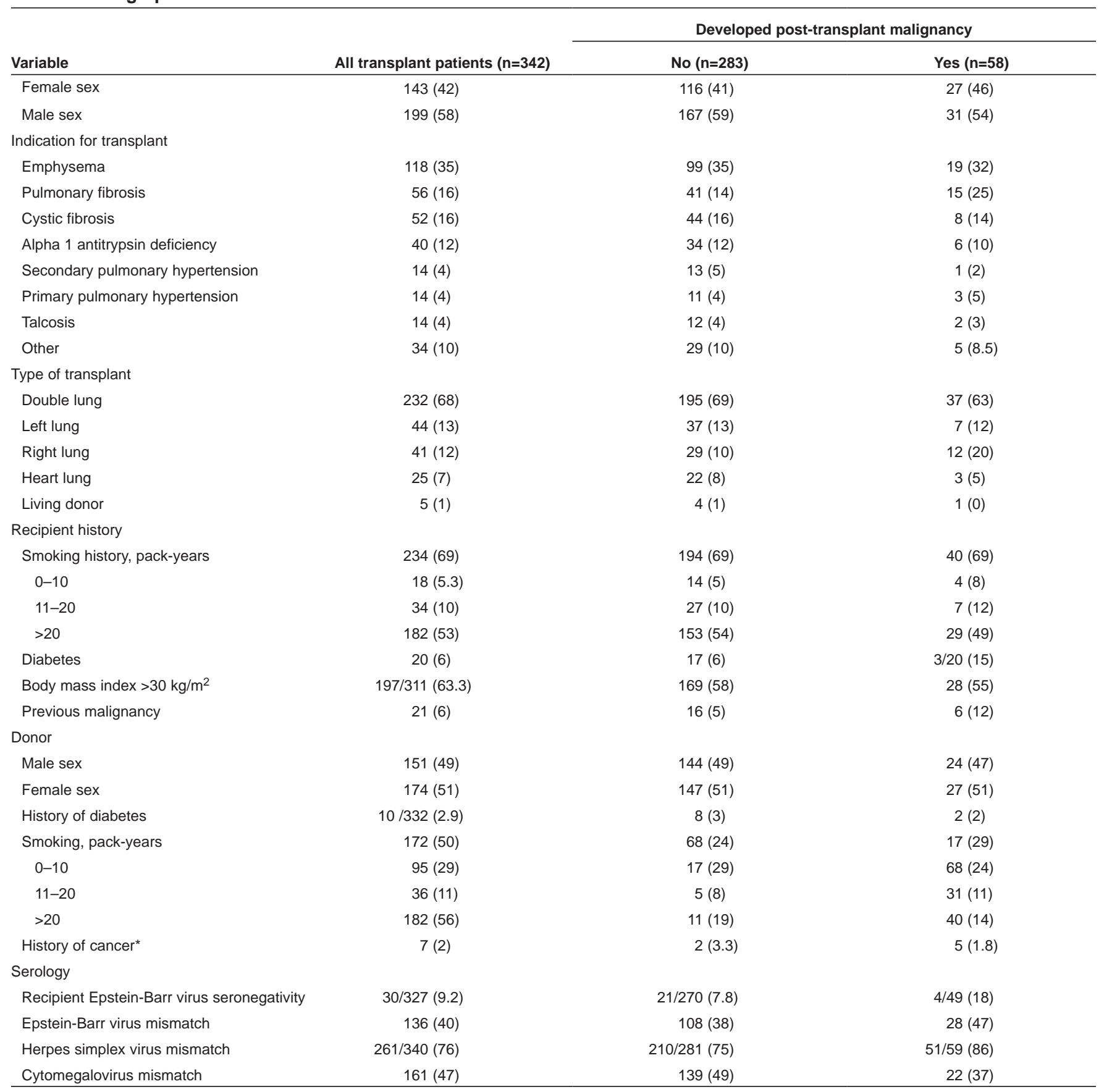

Data are presented as $n$ (\%). *Donor history of cancer included only benign lesions in the central nervous system and squamous cell carcinoma or basal cell carcinoma

types of tumours in a post-transplant population of lung and heart-lung recipients, the effect of malignancy on survival and the risk factors that may predispose to its development.

\section{METHODS}

The present study was a retrospective review of all lung and heart-lung transplant recipients at the University of Alberta (Edmonton, Alberta) from 1986 to May 2007. Ethics approval was obtained from the University of Alberta Health Research Ethics Board. All patients and all forms of malignancy were included in the present study. Patient follow-up was until either death or May 2007. Follow-up was performed by chart review at the University of Alberta Lung Transplant Program along with analysis of the Alberta Cancer Registry. If a patients's follow-up was not complete at this point, his or her individual family doctor and/or provincial cancer registry was contacted.

The primary outcome measures included the morphology and location of any malignancies, survival postlung transplantation and cause of death. Donor and recipient variables collected included the indication for lung transplantation, the morphology and site of any previous cancer, smoking history, Epstein-Barr virus (EBV), herpes simplex virus and cytomegalovirus serological status, comorbidities of cardiovascular 
disease, diabetes as well as demographic data. Treatment variables collected included the type of transplant received and the form of post-transplant immunosuppression.

Induction immunosuppression with a polyclonal antilymphocyte globulin is routinely used in the program. All patients received standard maintenance immunosuppression with a triple drug regimen that included a calcineurin inhibitor, a corticosteroid and an antimetabolite. The calcineurin inhibitor used was either cyclosporine $\mathrm{A}$ or tacrolimus. The antimetabolite used was either azathioprine or mycophenolate mofetil. Data regarding which therapy patients were receiving at three months, one year, three years and five years, were collected. Patients' cumulative length of time on each drug was calculated based on the assumption that the patient remained on the same form of immunosuppression between the measured time intervals.

\section{Statistical analysis}

Descriptive statistics included the use of means, medians and SDs. Univariate associations between risk factors and outcomes were analyzed using Fisher's exact tests, $\chi^{2}$ tests and logistic regression. Risk factors that were found to be associated with the development of post-transplant malignancy at $\mathrm{P} \leq 0.10$ were included as covariates in a multivariable logistic regression model predicting the development of post-transplant malignancy and post-transplant lymphoproliferative disorders (PTLDs). Predictors of the development of post-transplant malignancy were maintained in the final logistic regression model if their association reached a level of significance of $\mathrm{P} \leq 0.05$. Survival analysis was performed using the KaplanMeier method. Comparisons of the survival distributions in subjects developing post-transplant malignancy with those not developing post-transplant malignancy was performed using the Wilcoxon (Breslow) test, given that survival curves crossed at nine months.

\section{RESULTS}

\section{Prevalence and risk factors}

The study population included 342 patients. The mean $( \pm$ SD) age of the transplant recipients was $48.6 \pm 13.3$ years. A summary of all the variables and their association with the development of malignancy is presented in Table 1. Variables examined included sex, diagnosis, type of transplant, donor and recipient history, and donor and recipient serology. The only association that was statistically significant for the development of malignancy was that of EBV serology, which is discussed in more detail below.

A total of 58 patients (17\%) developed a post-transplant malignancy. Eleven patients had two independent post-transplant malignancies and one patient developed four. In total, 73 neoplasms developed in 342 patients. In cases of multiple malignancies, either a squamous cell carcinoma (SCC) or basal cell carcinoma (BCC) was involved at least once. The median time to diagnosis was less than 2.5 years (Figure 1). This delayed onset is an important factor in considering the effect of the development of malignancy on survival and is addressed in the discussion.

The most common types of malignancy were SCC of the skin $(\mathrm{n}=22)$ and PTLDs $(\mathrm{n}=17)$. Other common malignancies were BCC of the skin $(n=14)$ and adenocarcinoma $(n=9)$ (Table 2).

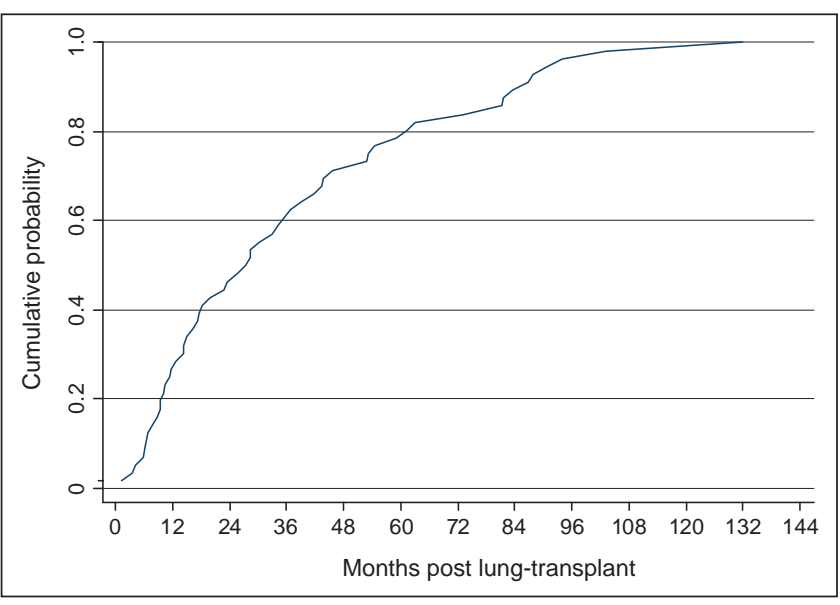

Figure 1) Cumulative probability of developing a post-transplant malignancy. Time until diagnosis of malignancy postlung and heartlung transplantation $(n=58)$. The median time until diagnosis of malignancy was slightly more than two years

\section{TABLE 2}

\section{Patient malignancy types}

\begin{tabular}{lc}
\hline Morphology of post-transplant neoplasms & $\mathbf{n}(\%)$ \\
\hline $\begin{array}{l}\text { Squamous cell carcinoma of skin (1 patient had a Bowen's } \\
\text { premalignant lesion) }\end{array}$ & $22(6.4)$ \\
Lymphoproliferative disorder & $17(5)$ \\
Basal cell carcinoma of skin & $14(4.1)$ \\
Nonbronchogenic adenocarcinoma & $8(2.3)$ \\
Bronchogenic carcinoma (3 small cell, 1 adenocarcinoma) & $4(1.1)$ \\
Malignant melanoma in skin & $2(0.6)$ \\
Kaposi sarcoma & $1(0.3)$ \\
Acute myeloid leukemia & $1(0.3)$ \\
Transitional cell carcinoma & $1(0.3)$ \\
Renal cell carcinoma & $1(0.3)$ \\
Solid organ sarcoma (unrecognized metastatic disease from & $1(0.3)$ \\
previous myxosarcoma of the heart) & \\
\hline
\end{tabular}

Of the 334 patients who received a lung transplant, 21 (6.3\%) were diagnosed with a pretransplant malignancy (PTM) either before or at the time of transplantation (Table 3). Three of the PTMs were incidental findings in the explanted lung (two SCCs and one adenocarcinoma). Six of these 21 patients developed a malignancy post-transplant; two were fatal recurrences of the pretransplant malignancy, while four were curable, independent, second primary tumours. There was no significant difference in the incidence of the development of post-transplant malignancy $(\mathrm{P}=0.10$ [Fisher's exact test]) or death as a result of post-transplant malignancy $(\mathrm{P}=0.194$ [Fisher's exact test]), regardless of whether patients had a previous diagnosis of malignancy.

There was no significant association between any of the variables outlined in Table 1 and the development of malignancy post-transplantation $(\mathrm{P}<0.05$ [Fisher's exact test]). An association between a history of pretransplant malignancy $(\mathrm{P}=0.10$ [Fisher's exact test]) or recipient seronegative EBV status at the time of transplant ( $\mathrm{P}=0.074$ [Fisher's exact test]) was evident but did not reach significance.

A younger recipient age at transplantation and recipient EBV seronegativity were strongly associated with the 
TABLE 3

Outcomes of 21 patients with a diagnosis of malignancy before lung transplantation

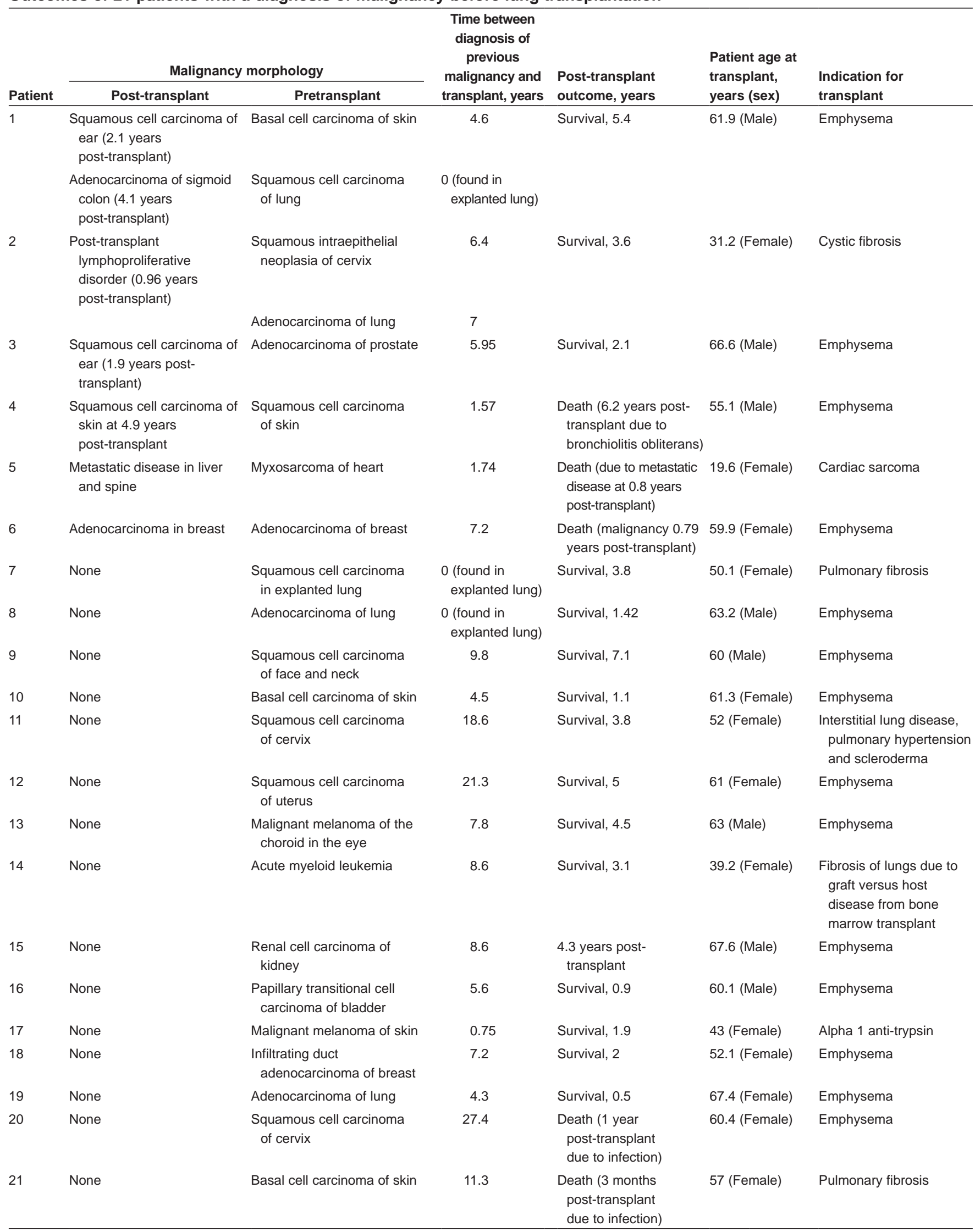


TABLE 4

Logistic regression model for the development of post-transplant lymphoproliferative disorders $(n=15)$

\begin{tabular}{lccccc}
\hline & OR & Standard error & z & P>lz| & 95\% Cl \\
\hline Age at transplantation & 0.991 & 0.025 & -0.35 & 0.723 & $0.944-1.041$ \\
Recipient Epstein-Barr virus seropositivity & 0.172 & 0.109 & -2.79 & 0.005 & $0.049-0.593$ \\
Donor smoking history & 0.583 & 0.420 & -0.75 & 0.454 & $0.142-2.39$ \\
\hline
\end{tabular}

development of PTLDs $(\mathrm{P}<0.001)$. Each decade of increasing age was associated with a reduced risk of the development of a PTLD $(\mathrm{OR}=0.64$ per decade; $95 \%$ CI 0.46 to 0.89). However, the prevalence of EBV seronegativity decreased with increments of increasing age $(\mathrm{P}<0.0001$ [Fisher's exact test]). When adjusted for age at transplantation and smoking history of the recipient, EBV seronegativity significantly increased the risk for the development of PTLDs (Table 4).

\section{Mortality and survival analysis}

Death due to malignancy was the third most common cause of death in the post-transplant population (Table 5). Fourteen patients who developed malignancy died as a result of it. The fatal forms of cancer in the present population were PTLD $(n=5)$, small cell lung carcinoma $(n=3)$, esophageal cancer $(n=2)$, liver and bone metastases from a myxosarcoma of the heart $(n=1)$, metastatic breast cancer $(n=1)$, SCC of the head and neck $(n=1)$, and advanced SCC of the tongue $(n=1)$. The myxosarcoma was considered to be an exceptional case and is discussed below.

The survival distribution between those who did and those who did not develop a post-transplant malignancy determined by the Kaplan-Meier method differed ( $\mathrm{P}=0.018$ Wilcoxon [Breslow]). Before 108 months (approximately nine years), individuals diagnosed with a post-transplant malignancy had an increased survival; however, after the ninth year posttransplant, they had a decreased survival rate (Figure 2). The median survival time in individuals without a post-transplant malignancy was 66.8 months (95\% CI 44.5 to 87.9 months) compared with 81.9 months (95\% CI 66.9 to 111.2 months) for those diagnosed with post-transplant malignancy. Patients who developed malignancy and died as a result of it had a significantly shorter survival time than those who died as a result of other causes (Figure 3).

Survival distribution determined by the Kaplan-Meier method did not differ between patients who did and those who did not develop a PTLD ( $\mathrm{P}=0.91$ [log-rank statistic]). The median survival time of individuals without a PTLD was 68.6 months (95\% CI 51.2 to 87.9 months) compared with 58.9 months (95\% CI 18.2 to undetermined, due to small sample size) for those diagnosed with a PTLD.

\section{DISCUSSION}

Overall, malignancy following cardiothoracic transplantation is increased compared with the general population, as reported recently by Roithmaier et al (9). The overall incidence of malignancy in our centre was $17 \%$ and predominantly consisted of SCC, BCC and PTLDs, which is well within the reported range of $16 \%$ to $18.7 \%(5,6)$. Malignancy accounted for $12 \%$ of all deaths postlung and heart-lung transplantation in our series, which is higher than that reported by the International Society for Heart and Lung Transplantation (6.5\%) (10) This could be due to a more complete follow-up in the present smaller series.
TABLE 5

Cause of death for patients receiving lung and heart transplants $(n=116)$

\begin{tabular}{lcccc}
\hline & & \multicolumn{3}{c}{ Survival, $\mathbf{n}$} \\
\cline { 3 - 5 } Cause of death & $26(22)$ & 10 & 8 & 8 \\
\hline Infection & Overall, $\mathbf{n}(\%)$ & $<\mathbf{1}$ year & years & >5 years \\
Bronchiolitis obliterans & $24(20)$ & 3 & 12 & 9 \\
Malignancy & $14(12)$ & 4 & 6 & 4 \\
Bronchial dehiscence & $12(10)$ & 11 & 1 & 0 \\
Acute rejection & $8(7)$ & 0 & 3 & 0 \\
Immediate graft failure & $7(6)$ & 7 & 0 & 0 \\
Gastrointestinal complication & $4(3)$ & 4 & 1 & 0 \\
Other & $21(21)$ & 10 & 9 & 2
\end{tabular}

Other casuses of death include cardiovascular disease, coagulopathies, intracranial air emboli, hemorrhage, renal failure, complications to scleroderma and unknown

We attempted to describe the risk factors for the development of all forms of malignancy in the post-transplant period. However, no variable that we analyzed demonstrated significance for the development of all forms of malignancy. A model specific for the development of PTLDs was significant when recipient age, recipient EBV seronegativity and smoking history at the time of transplantation were included. Donorrecipient EBV mismatch was not used in the model, and recipient EBV seronegativity was more strongly associated with the development of PTLD than a donor-recipient EBV mismatch $(\mathrm{P}=0.055$ versus $\mathrm{P}=0.119$, respectively [Fisher's exact test]).

The strongest association with malignancy in the posttransplant period was a PTM. Six of the 21 cases in the PTM group developed a post-transplant malignancy, and two of these six cases were recurrences. The first was a breast cancer diagnosed 7.1 years before transplant, which was fatal at 288 days post-transplant. PTM has been identified as a large risk in other solid organ transplantations (11). The second case of recurrence was a potential curative heart-lung transplant for a 19-year-old woman with myxosarcoma of the heart. There was no apparent metastatic disease at the time of transplant; however, approximately 10 months after transplant, metastases in her liver and spine were evident.

Bronchogenic carcinoma developed in $1.17 \%$ (four of 342) of the cohort, occurring in $2.35 \%$ (two of 85 ) of single lung transplant (SLTx) recipients and $0.82 \%$ (two of 257) of bilateral lung and heart-lung recipients. Of the SLTx recipients, both tumours developed in the native lung and only one recipient was a smoker. The development of bronchogenic carcinoma has been noted in all forms of solid organ transplantation and has been linked primarily to patients with a smoking history as well as to oncogenes transferred at the time of transplantation (12). For pulmonary transplantation specifically, SLTx has been shown to have a greater risk for the development of 


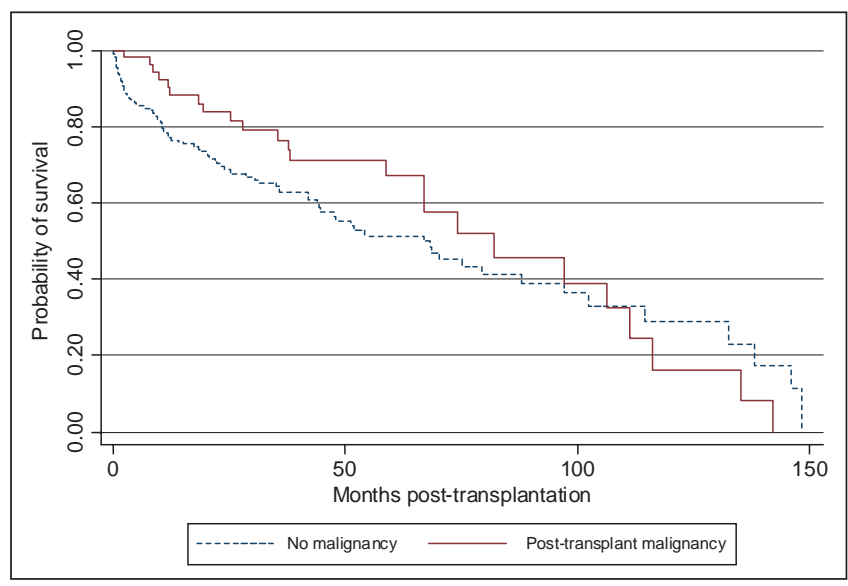

Figure 2) Kaplan-Meier survival estimate. Lung transplant recipients who developed a malignancy had a longer median survival time than those who did not develop a malignancy $(P=0.018$ Wilcoxon [Breslow])

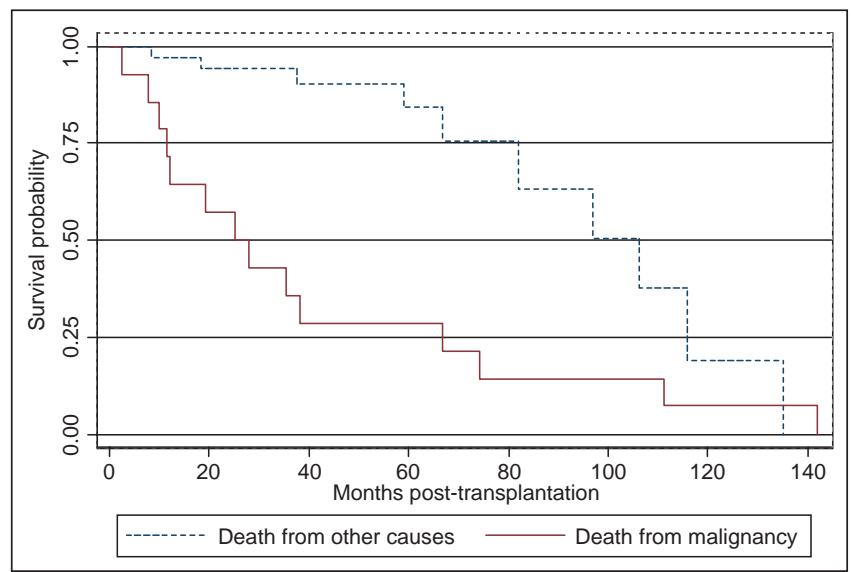

Figure 3) Kaplan-Meier survival estimates. In patients who developed malignancy post-transplant $(n=58)$, those who died as a result of their malignancy $(n=14)$ had a significantly shorter survival than those who died of other causes $(n=45)(P<0.001$ Wilcoxon [Breslow])

bronchogenic caricinoma (13); however, several studies have reported findings of bronchogenic carcinoma in bilateral lung transplant recipients $(14,15)$.

Smoking is a proven risk factor for lung and nonlung cancers. In the renal transplant population, smoking has been shown to have an RR of 1.91 for the development of malignancy; quitting smoking more than five years before transplantation was not beneficial (16). In the present cohort, a smoking history (as well as a diagnosis of chronic obstructive pulmonary disease) was not associated with the development of malignancy or the incidence of bronchogenic carcinoma posttransplant. One of two SLTx recipients who developed a bronchogenic carcinoma was a previous smoker who underwent transplant for emphysema, while the other was a nonsmoker with severe idiopathic pulmonary fibrosis (IPF).

In our series, the three patients who developed a fatal course of small cell bronchogenic carcinoma were originally diagnosed with IPF. Although the diagnostic indication for transplantation was not statistically significant for the development of any malignancy $(\mathrm{P}=0.885)$, IPF showed an increased prevalence of malignancy in our series. Fifty-six patients had IPF (16\% of the population), $25 \%$ of whom developed malignancy. This may be attributable to their previous use of immunosuppression as treatment for their IPF.

We measured the exposure of each patient to each immunosuppressive therapy by the number of months each patient was on that respective drug and assumed that each patient was within the target dosage. There were no statistically significant differences between any immunosuppressant and the incidence of malignancy. This has been reported in other clinical literature $(10,17)$ despite certain in vitro studies predicting otherwise $(18,19)$.

As previously reported in other solid organ transplant studies (20-22), the results of the present study showed no association between malignancy and decreased survival. Our study did not show statistical significance between a history of malignancy and the development of post-transplant malignancy. However, two important factors regarding the effect of malignancy on survival were distinguished. First, in Figure 1, we showed that the time to development of malignancy is significant, with a median time of greater than two years. Second, we showed that not all malignancies were fatal and that individuals who died as a result of their malignancy had a significantly shorter survival time than those who developed malignancy but died of other causes. Furthermore, we demonstrated in two specific cases that certain PTMs can have rapid and aggressive onset post-transplantation. This offers an interesting perspective to the principle that previous malignancy within two years is a contraindication to lung transplantation (23-25).

\section{CONCLUSION}

The development of malignancy is common and is a significant concern in the postlung and heart-lung transplant patient. Development of malignancy was not associated with decreased survival. This may be secondary to the length of time required to develop malignancy and the fact that not all malignancies that developed were fatal. The median time to develop malignancy was greater than two years. As well, the patients who died as a result of their malignancy had a significantly shorter survival than those who died due to nonmalignant causes $(\mathrm{P}<0.001)$. Of the variables analyzed, EBV seronegativity at the time of transplant was identified as being a significant risk factor for a PTLD.

\section{REFERENCES}

1. Hosenpud J, Bennett L, Keck B, Edwards E, Novick R. Effect of diagnosis on survival benefit of lung transplantation for end-stage lung disease. Lancet 1998;351:9095.

2. Charman SC, Sharples LD, McNeil KD, Wallwork J. Assessment of patient survival benefit after lung transplantation by patient diagnosis. J Heart Lung Tranplant 2002;24:968-82.

3. Geertsma A, ten Verget EM, Bonsel JG, de Boer WJ, Vander BW. Does lung transplantation prolong life? A comparison of survival with and without transplantation. J Heart Lung Transplant 1998;17:511-6.

4. Adami J, Gabel H, Lindelof B, et al. Cancer risk following solid organ transplantation: A nationwide cohort in Sweden. Br J Cancer 2003;89:1221-7.

5. Amital A, Shitrit D, Raviv Y, et al. Development of malignancy following lung transplantation. Transplantation 2006;4:547-51.

6. Trulock EP, Edwards LB, Taylor DO, Boucek MM, Keck BM, Hertz MI. Registry of the International Society for Heart and Lung Transplantation: Twenty-third Official Adult Lung and Heart-Lung Transplantation Report - 2006. J Heart Lung Tranplantation 2006;25:880-92. 
7. Gutierrez-Dalmau A, Campistol JM. Immunosuppressive therapy and malignancy in organ transplant recipients: A systematic review. Drugs 2007;67:1167-98.

8. Knoop C, Haverich A, Fisher S. Immunosuppressive therapy after human lung transplantation. Eur Resp J 2004;23:159-71.

9. Roithmaier S, Haydon AM, Loi S. Incidence of malignancies in heart and/or lung transplant recipients: A single-institution experience. J Heart Lung Transplant 2007;26:845-9.

10. Campbell A, Moazami N, Ditkoff BA, Kurtz E, Estabrook A, Schnabel F. Short-term outcome of chronic immunosuppression on the development of breast lesions in premenopausal heart and lung transplant patients. J Surg Res 1998;78:27-30.

11. de Perrot M, Wigle DA, Pierre AF, et al. Bronchogenic carcinoma after solid organ transplantation. Ann Thorac Surg 2003;75:361-7.

12. Dickson RP, Davis RD, Rea JB, et al. High frequency of bronchogenic carcinoma after single-lung transplantation. J Heart Lung Transplant 2006;25:1297-301.

13. Collins J, Kazeroni EA, Lacomis J, et al. Bronchogenic carcinoma after lung transplantation: Frequency, clinical characteristics, and imaging findings. Radiology 2002;224:131-8.

14. Arcasoy SM, Hersh C, Christie JD, et al. Bronchogenic carcinoma complicating lung transplantation. J Heart Lung Tranpslant 2001;20:1044-53.

15. Kasiske BL, Klinger D. Cigarette smoking in renal transplant recipients. J Am Soc Nephrol 2000;11:753-9.

16. Robson RR, Robson JM, Cecka G, Budde OM, Sacks S. Prospective registry-based observational cohort study of the long-term risk of malignancies in renal transplant patients treated with mycophenolate mofetil. Am J Transplant 2005;5:2954-60.
17. O'neill JO, Edwards LB, Taylor DO. Mycophenolate mofetil and risk of developing malignancy after orthotopic heart transplantation: Analysis of the transplant registry of the International Society for Heart and Lung Transplantation. J Heart Lung Transplant 2006;25:1186-91.

18. Tressler RJ, Garvin LJ, Slate DL. Anti-tumor activity of mycophenolate mofetil against human and mouse tumors in vivo. Int J Cancer 1994;15:568-73.

19. Blaheta RA, Bogossian H, Beecken WD, et al. Mycophenolate mofetil increases adhesion capacity of tumor cells in vitro. Transplantation 2003;27:1735-41.

20. Delgado JF, Crespo MG, Pulpon LA, et al. Pre-existing neoplasms and risk for malignancy after heart transplantation. Data from the Spanish Post-Heart Transplant Tumors Registry. J Heart Lung Transplant 2007;26:S124-5.

21. Koerner MM, Tenderich G, Minami K, et al. Results of heart transplantation in patients with pre-existing malignancies. Am J Cardiol 1997;79;988-91.

22. Ladowski SD, Abel M, Beatty L, et al. Long-term follow-up of heart transplant recipients with pre-transplant malignancies. Tex Heart Inst J 2006;33:27-30.

23. Penn I. Evaluation of transplant candidates with pre-existing malignancies. Ann Transplant 1997;2:14-7.

24. Villanueva J, Garrity E. How to select patients for lung transplantation: Guidelines for recognizing appropriate candidates in time for success. J Crit Ill 2001;16:126-32.

25. Orens JB, Estenne ME, Arcasoy S, et al. International guidelines for the selection of lung transplant candidates: 2006 update - a consensus report from the Pulmonary Scientific Council of the International Society for Heart and Lung Transplantation. J Heart Lung Transplant 2006;25;745-55. 


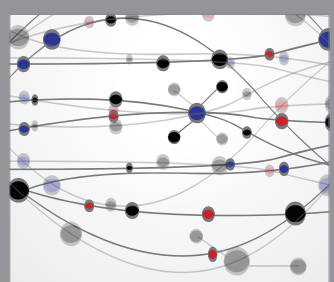

The Scientific World Journal
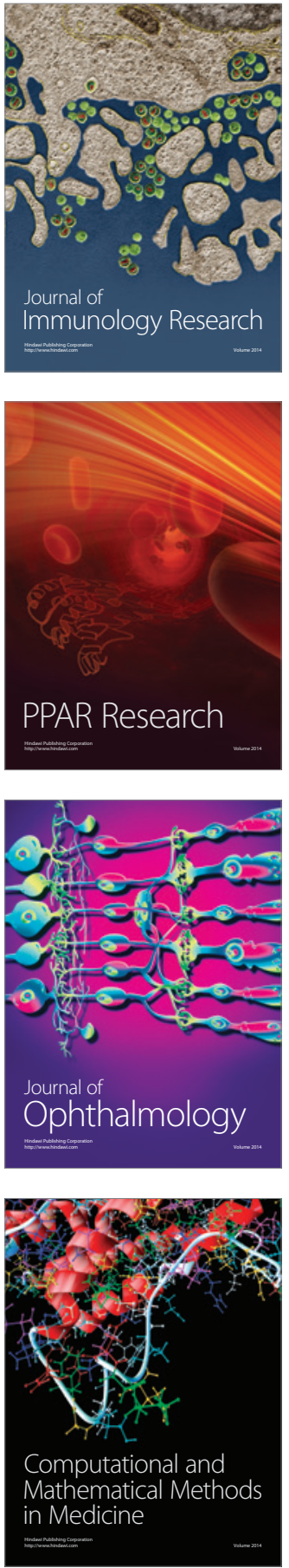

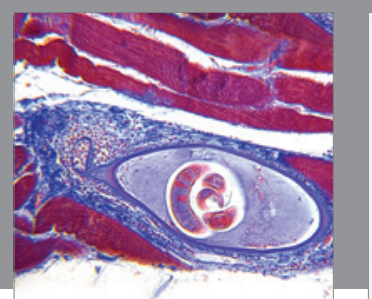

Gastroenterology Research and Practice

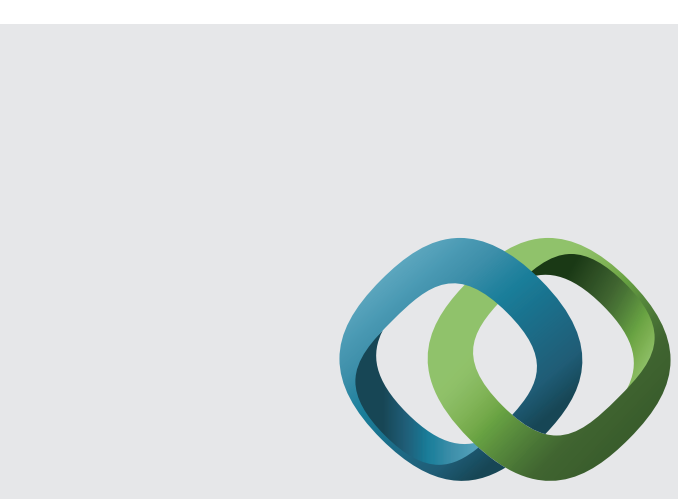

\section{Hindawi}

Submit your manuscripts at

http://www.hindawi.com
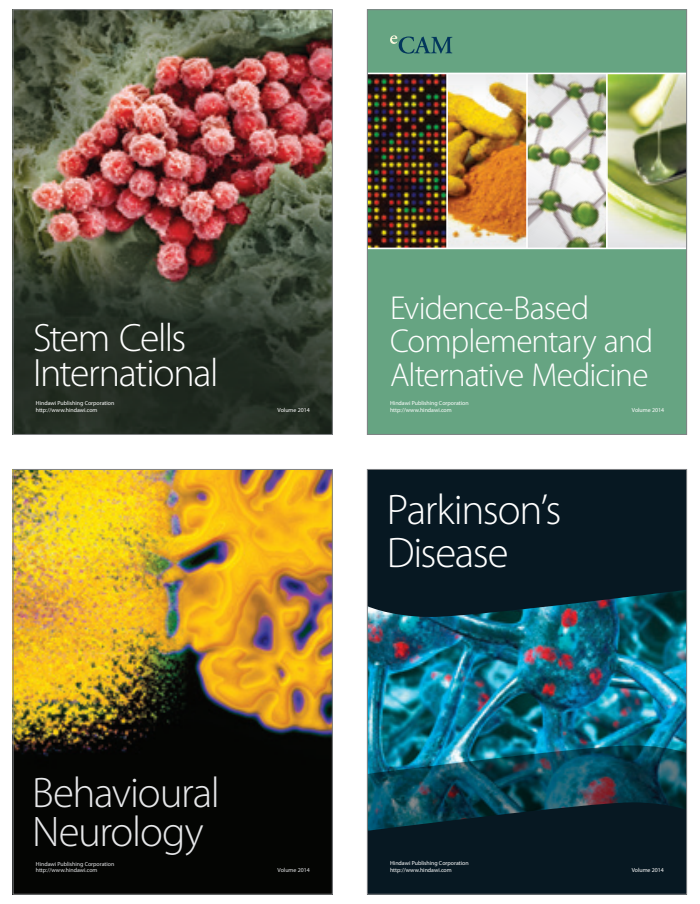
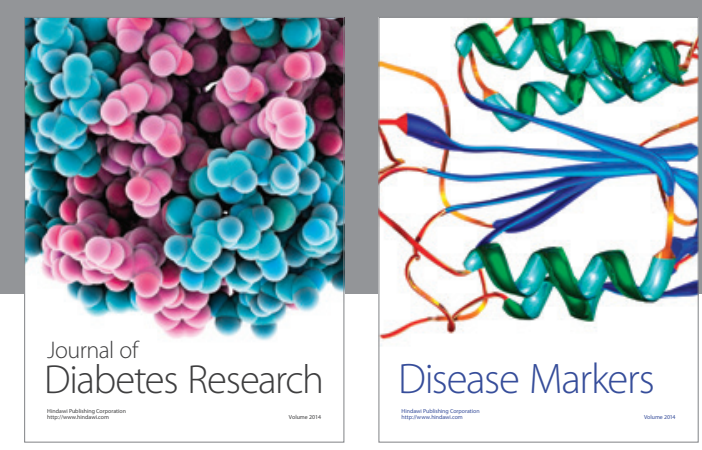

Disease Markers
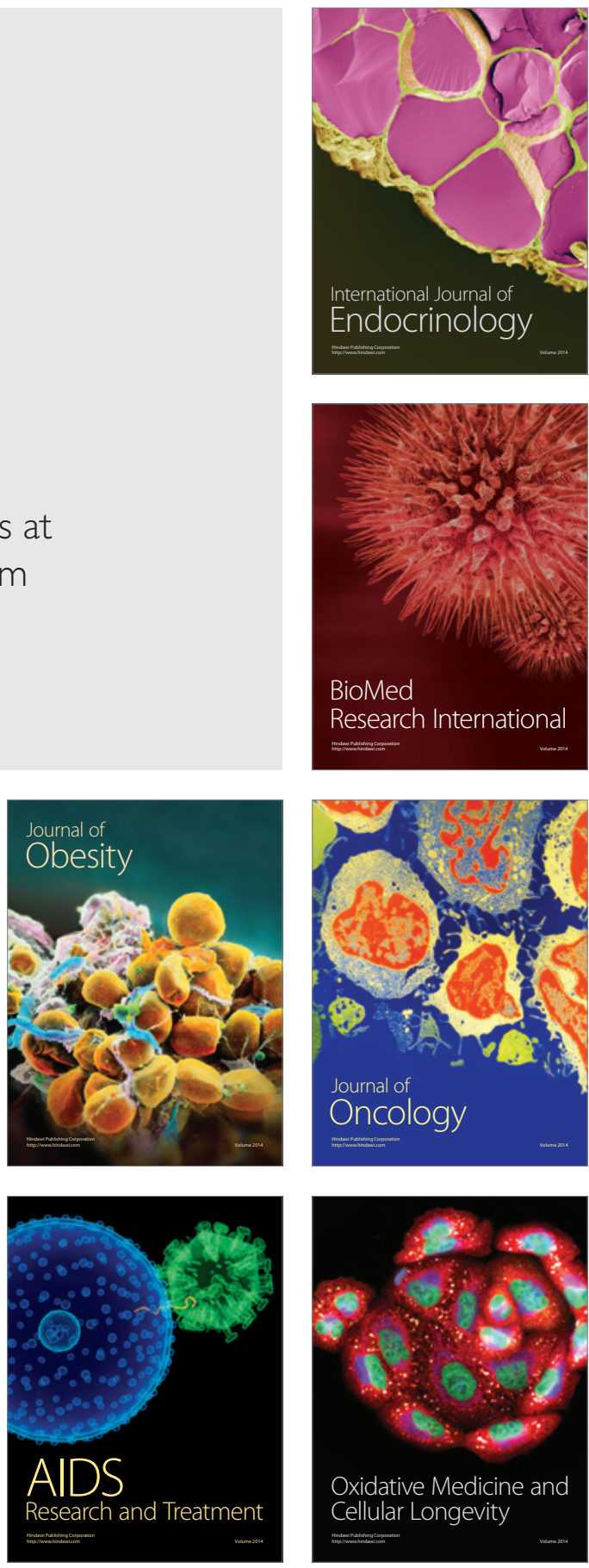